\title{
Örgütlerde Kişisel İtibarın Önemi ve Örgütlere Sağladığı Faydalar: Bir Literatür Taraması
}

\section{Benan Gok ${ }^{\mathrm{a}}$}

Öz: Kişisel itibar, bireyin belirgin kişisel özelliklerini ve başarılarını gösterdiği ve bireyin doğrudan gözlemlenen veya ikincil kaynaklardan bildirdiği davranışları yansıttığı algısal bir kimliktir. Günümüz rekabet dünyasında, örgütlerde itibar kavramı sıklıkla kullanılmaktadır. Itibarın mikro düzeyi olan kişisel itibarın önemi özellikle bireyin kariyeri, insan kaynakları kararları ve iş sonuçları üzerinde önemli etkiler göstermektedir. Uluslararası işletme literatüründe örgütlerde kişisel itibarı konu alan çalışmaların ilgili literatüre zenginlik katmaya devam ettiği; ulusal literatürde ise yeterince araştırma yapılmadığı tespit edilmiştir. Bu çalışmada, ulusal işletme literatüründe yetersiz olarak görülen kişisel itibarın kavramsallaştırılması ile birlikte itibarların nasıl geliştirildiği ve bir örgüte nasıl yayıldığı çeşitli teoriler aracılığıyla incelenmiştir. Buna ek olarak, kişisel itibarın bireylere ve örgütlere hangi faydaları sağladığı açıklanmıştır. Son olarak genel bir değerlendirme yapılmış ve gelecekteki araştırmalar için öneriler sunulmuştur.

\section{The Importance of Personal Reputation in Organizations and Its Benefits to Organizations: A Literature Review}

\begin{abstract}
A personal reputation is a perceptual identity in which an individual shows obvious personal characteristics and achievements and reflects the behavior that the individual reports directly from observed or secondary sources. In today's competitive world, the concept of reputation is frequently used in organizations. The importance of personal reputation, which is the micro level of reputation, especially has significant effects on an individual's career, human resources decisions, and business results. It has been determined that the studies on personal reputation in organizations continue to add richness to the relevant literature in the international business literature, and there has not been enough research in the national literature. In this study, the conceptualization of personal reputation, which is seen as inadequate in national business literature, and how reputations are developed and how they spread to an organization are examined through various theories. It is also explained what benefits personal reputation brings to individuals and organizations. Finally, a general assessment was made, and recommendations for future research were presented.
\end{abstract}

Anahtar Sözcükler: İtibar, Kişisel İtibar, İşyeri, Çalışanlar, Politik Beceri, i̇ş Performansı

JEL: M12, M19

$\begin{array}{ll}\text { Geliş } & : 14 \text { Eylül } 2021 \\ \text { Düzeltme } & : 16 \text { Kasım } 2021 \\ \text { Kabul } & : 27 \text { Aralık } 2021 \\ & \\ \text { Tür } & : \text { Derleme }\end{array}$

Keywords: Reputation, Personal Reputation, Workplace, Employees, Political Skill, Job Performance

JEL: M12, M19

Received : 14 September 2021 Revised : 16 November 2021 Accepted : 27 December 2021

Type : Review 


\section{Giriş}

Kişisel itibar, göze çarpan kişisel özelliklerin, başarıların, sergilenen davranışların ve belirli bir süre boyunca doğrudan gözlemlenen ve amaçlanan davranışların karışık birleşimini yansıtan algısal bir kimliktir (Ferris vd., 2003: 215). Kişisel itibar, bireylerin sosyal etkileşimlerine dayalı olarak oluşan bir dizi izlenim veya davranışsal beklentiyi yansıtmaktadır (Foste ve Botero, 2012: 49). Kişisel itibarın temeli, bireyin geçmiş davranışlarına, eylemlerine, kişiliğine, beşeri sermayesine (ör. eğitim) ve sosyal etkinliğine (ör. sosyal beceri, politik beceri) dayanmaktadır. Bu bilgilerden ve eylemlerin gözleminden yola çıkarak izleyiciler, birey hakkında algı oluşturmaktadır. Bu algılar, daha sonra belirli bir bağlamda o bireyin kişisel itibarını oluşturmaya devam etmektedir (Ferris vd., 2014: 244-245). Diğer bir deyişle itibar, bir bireyin belirli gözlemlenebilir kişisel özelliklerinden ve başarılarından etkilenmektedir (Ferris vd., 2003: 216; Zinko vd., 2017a: 632). ìtibarın günlük yaşamda temel bir gerçekliği olduğu gibi, örgütsel yaşamda da önemli bir rolü bulunmaktadır. Örgütsel yaşamda inşa edilen itibarlar, bireylerin işlerini etkili bir şekilde yerine getirme ve izleyicileriyle işbirliği geliştirme konularına odaklanmaktadır. Böylece birçok kişi, işyerinde kendileri hakkında olumlu bir itibar yaratmaya çalışmaktadır (Zinko vd., 2012: 156-157). Örneğin, olumlu itibara sahip bireyler, istihdam için daha uygun görülmekte, işe alındıktan sonra daha az izlenme ve hesap verebilirlik durumlarıyla karşılaşmaktadırlar. Buna ek olarak, bu bireylere daha fazla bilgi, işbirliği ve artan ödüller verilmektedir (Laird vd., 2013: 661). Olumlu bir itibara sahip olmak değerli faydalar sağladığı için bireylerin genellikle bu konuya önemli miktarda kaynak ayırdıkları ileri sürülmektedir (Jazaieri vd., 2019: 965).

Uluslararası literatürde itibarın mikro düzeyi olan kişisel itibarın kavramsal temellerini, süreç dinamiklerini ve örgütlere sunduğu avantajları inceleyen kapsamlı çalışmalar bulunmaktadır (bkz. Ferris vd., 2003; Zinko vd., 2007; Zinko vd., 2012; Foste ve Botero, 2012; Laird vd., 2013; Zinko vd., 2017a; Jazaieri vd., 2019). Ancak ulusal literatürde itibarın makro düzeyi olan kurumsal itibarın ağırlıklı olarak ön planda olduğu; kişisel itibar kavramına ilişkin çalışmaların ise oldukça kısıtlı olduğu görülmektedir (bkz. Cömert ve Uzun, 2014; Demirbağ vd., 2020; Gök ve Çiftçioğlu, 2021; Küçük ve Demirbağ, 2021). Uluslararası literatür kişisel itibarı hem bireysel hem de örgütsel temelde açıklamaktadır. Olumlu itibara sahip bireyler, daha yetkin, daha yüksek statüye sahip ve güvenilir olarak algılanmaktadır. İtibarlı bireyin bir örgütle birlikte algılanması işletmeye olumlu sonuçlar sağlamaktadır. Örneğin, örgütler, kurumsal sermaye yatırımlarını ve kurumsal performansı artırmak, kendi kurumsal itibarlarını oluşturmak, çalışanları ve yatırımcıları örgüte çekmek veya korumak, paydaşların gözünde güven oluşturmak, tüketicilere ve rakiplere bilgi vermek için kişisel itibarları kullanmaktadırlar (Gaines-Ross, 2000; Ranft vd., 2006; Hochwarter vd., 2007; Foste ve Botero, 2012; Zinko vd., 2012; Goldin, 2016). Çünkü bireyin itibarı, paydaşlar nezdinde örgüt potansiyelini ortaya çıkaran bir sinyal görevi görmektedir (Certo, 2003). Günümüz rekabet ortamında kişisel itibarın özellikle örgütsel kazanımları göz önüne alındığında, ulusal işletme literatüründe yetersiz olarak görülen kişisel itibarın kavramsallaştırılması, itibarların nasıl geliştirildiği ve bir örgüte nasıl yayıldığını incelemek önem arz etmektedir. Dolayısıyla bu çalışma, kişisel itibar kavramına ilişkin ulusal literatürün eksikliğini ele alma ve ilgili literatüre bilimsel katkı sağlama amacı gütmektedir.

Bu çalışmada öncelikle, itibar kavramının çerçevesi ve kişisel itibarın tanımı oluşturulmakta, ardından yönetim literatüründe kişisel itibar üzerine mevcut araştırmaların teorik incelemesi verilmektedir. Daha sonra, kişisel itibar kavramının kuramsal temelleri, ilgili kavramın öncülleri ve kişisel itibarın nasıl oluşturulduğu irdelenmektedir. Son olarak, kişisel itibarın sonuçları ve örgütlere sağladığı faydalar açıklandıktan sonra gelecek çalışmalar için önerilerde bulunulmaktadır.

\section{Yönetim Literatüründeki İtibarı Anlamak}

İtibar Arapça bir kelime olup saygınlık ve güvenilirlik anlamına gelmektedir (www.tdk.gov.tr). Latince'de itibar kelimesi itimat etmek anlamına gelen "reputance" kelimesinden türemiştir (Balmer, 1998: 970). Almanca'da itibar, takdir etmek, saygı duymak ve ün, şan, şöhret ile eş anlamlı olarak kullanılmaktadır. Amerikan sözlüklerinde itibarın "birinin/bir şeyin yetenekleri, özellikleri vb. hakkında genel olarak söylenen veya inanılan şey" olarak tanımlanmaktadır (Schwaiger, 2004: 48). Bu çerçevede itibar; güvenilir, inanılabilir, saygın, beğenilme gibi olumlu değerlerle tasvir edilen sonuçlar olarak tanımlanmaktadır. 
Yönetim literatüründeki itibar hem mikro hem de makro düzeyde incelenmektedir. İtibarın makro düzeyi olan kurumsal itibar; işletmenin tüm paydaşlarının işletmenin ismine yönelik inşa ettikleri algılardır (Fombrun, 1996: 37). İtibar, işletme dışındakilerin bu örgütü tanımlamak için kullandıkları özelliklerden oluşmaktadır (Fombrun ve Shanley, 1990: 233). Buna göre kurumsal itibar; gerçeklik, dürüstlük ve sorumluluk gibi işletmeye iliş̧in oluşturulan değerler bütünüdür ve uzun vadeli duyguları, değerleri, düşünceleri içine alan bir kavramdır (Dowling, 2001: 19). Buradan, kurumsal itibarın bilgiye dayalı ve duygusal unsurları içine alan bir kavram olduğu anlaşılmaktadır (Hall, 1992: 138). Kurumsal itibarın potansiyel olarak olumlu sonuçları vardır. Olumlu itibar; tüketicilere ürün kalitesi hakkında sinyal vermekte, firmaların daha yüksek fiyatlar talep etmelerini sağlamakta, daha kalifiyeli potansiyel çalışanları örgüte çekmekte, sermaye piyasalarına erişimi arttırmakta ve yatırımcıları örgüte yakınlaştırmaktadır (Fombrun ve Shanley, 1990: 233).

Kurumsal itibar, diğer bireylerin bir örgütü belirli bir süre boyunca nasıl değerlendirdiği üzerinde durmaktadır. İtibar, örgütler için büyük anlam ifade etmektedir. Çünkü itibar, örgüt için rekabet avantajının oluşturulmasına ve sürdürülmesine katkıda bulunabilecek maddi olmayan varlık olarak görülmektedir. Örgütlerin birçok paydaş gruplarıyla ilişkilerini etkin bir biçimde sürdürmeleri başarılı bir itibar için önemli bir unsur olarak kabul edilmektedir. Çünkü itibar, bu paydaş gruplarının örgüte gerekli kaynakları sağlamaya ikna etmek için kullanılmaktadır.

İtibarın mikro düzeyi olan kişisel itibar, başkalarının kolektif algılarında oluşan, göze çarpan kişisel özelliklerin, gösterilen davranışların ve belirli bir süre boyunca doğrudan gözlemlenen veya ikincil kaynaklardan bildirilen imgeleri yansıtan algısal bir kimliktir (Zinko vd., 2007: 165). Kişisel itibar, tanımlanmış bir sosyal ağdaki üyeler tarafından paylaşılan ve ifade edilen birbirine bağlı izlenimler çekirdeği olarak tanımlanmaktadır (Bromley, 1993: 42). İtibar, algısal bir kavram olmasından dolayı son derece özneldir ve diğer bireylerin gözünde tanımlanan ve sosyal olarak inşa edilmiş bir gerçekliktir (Ferris vd., 2003: 216). İtibarın iletişimle ortaya çıkan ve grup üyeleri arasında paylaşılan bir kavram olduğu vurgulanmaktadır (Jazaieri vd., 2019: 965). Örneğin, Hogan ve Holland (2003), izleyicilerin bir kişinin geçmiş davranışlarını göz önünde bulundurduklarını ve bu bireyin kişiliği hakkında bir izlenim oluşturduklarını savunmaktadırlar. Gerçekte itibar, eylemlere dayalı olsa da itibar yaratan bu eylemler, izleyicilerin değerlendirmelerini kapsamaktadır (Ferris vd., 2014: 245). Bu çerçevede kişisel itibar, başkalarının bir bireyin özellikleri veya davranışlarına ilişkin toplam yargılamalarının bütününe işaret etmektedir.

İtibarın gelişmesine yol açan davranışların daha büyük gruplara raporlanması ve daha sonra bu davranışların izleyici gruplar içindeki bireyler tarafından tartışıması gerekmektedir. Aslında, bu davranışları değerlendirecek bir izleyici kitlesi olmadan, bireyin üzerinde mutabık kalınan bir değerlendirme (yani itibarları) gelişmesi mümkün değildir (Zinko vd., 2007: 185). İtibarın oluşmasında çevredeki izleyicilerin önemi dikkate alındığında, bir bireyin çevresindeki izleyicilerden geri yansımalar alması gerekmektedir. Bu sayede, bireyin kendi itibarı hakkında hedeflediklerinin ne kadarını elde ettiğine dair geri bildirim sağlamasına da imkân vermektedir (Ranft vd., 2006: 280). Örneğin bir birey, beklenenin ötesinde büyük başarılar elde edebilmektedir, ancak bu başarıları başkalarına iletecek gözlemciler yoksa itibar gelişmemektedir. Benzer şekilde, bir kişi uygunsuz davranışlarda bulunuyorsa ve izleyiciler tarafından gözlemlenmiyorsa, olumsuz bir itibarın ortaya çıkması da mümkün değildir (Zinko vd., 2017b: 520). Birçok birey, ne tür bir itibar geliştirdiklerini önemsemekte ve belirli itibar özelliklerini korumak ve inşa etmek için hareket etmektedir. Bu özelliklerin en önemlileri arasında çekicilik, prestij, saygı, statü ve güvenilirlik yer almaktadır. Bazı bireyler uzun vadeli parasal getiri elde etmek için finansal yatırımlar yaptıkları gibi bazı bireyler de diğer bireyleri etkileme konusunda uzun vadeli etkinlik sağlayacak özelliklere sahip olma konusunda itibar geliştirmek için zaman ve çaba harcamaktadırlar (Tedeschi ve Melburg, 1984: 42-43).

İtibar geliştirme süreci içinde değerli kavramlardan biri olarak görülen izlenim yönetimi bireylerin başkalarının kendileri hakkında oluşturduğu izlenimleri kontrol etmeye çalıştı̆̆ı süreci yansıtmaktadır. Bireyler genellikle başkalarının kendilerini nasıl algıladıklarını bilmemektedirler. Ancak bireyler, zaman zaman başkalarını nasıl etkilediklerini hissetmek ve olumlu izlenimler elde etmek için davranışlarını değiştirmeye çalışmaktadırlar (Amaral vd., 2019: 315-316). Genellikle bireylerin izlenimlerini yönetmek için kullanabilecekleri farklı etkileme davranışları; taktikler (yani kısa vadeli) ve stratejiler (yani uzun vadeli) olarak kategorize edilmektedir. İzlenim yönetimi stratejilerinin itibar geliştirme etkisine sahiptir ve ister gerçek ister 
algılanmış olsun, tekrarlanan tutarlı davranışın bir itibar oluşumuna katkısı bulunmaktadır. Bu sebeple bireyler, kendilerine yararlı buldukları belirli bir kimliği yaratma ve sürdürme amaçlarına sahip oldukları için kendi izlenimlerini yönetmek için motive olmaktadırlar. Bunu yapmak için, istenen kimliğe uygun ve tutarlı davranmaları gerekmektedir (Ranft vd., 2006: 280). İtibar, sadece izlenim yönetimi davranışlarıyla geliştirilip sürdürülmekle kalmamakta, aynı zamanda kasıtlı olarak yapılan eylemlerini de kapsamaktadır (Greenberg, 1990: 138). Örneğin, bir kişinin başkalarıyla olan yakınlık algısı, bu bireyin iyi bir performans sergilediği algısını oluşturarak itibarını da artırabilmektedir. Bazen bireyler statülü ya da güçlü olan bireylerin yakın çevrelerinde oldukları ve onlarla sıkça vakit geçirdikleri izlenimini vermeye çalışmaktadırlar. Bu da bireylerin kendi itibarlarını artırmalarını sağlayarak etrafındaki prestijli görülen sosyal ağlara bağlanmalarına sebep olmaktadır (Ranft vd., 2006: 280).

Kişisel ve kurumsal itibar kavramlarına ilişkin tekrar eden ortak özellikler bulunmaktadır. Birincisi, itibar zamanla inşa edilmektedir. İkincisi, olumlu bir itibara sahip birey veya örgüt üzerinde itibarın kalıcı, uzun vadeli bir etkisi bulunmaktadır. Üçüncüsü, itibar genellikle izlenim yönetimi teknikleri ve medyanın stratejik kullanımı yoluyla yönetilmektedir ve manipüle edilebilmektedir (Ranft vd., 2006: 280). Buna ek olarak itibar, modern toplumun her alanında bulunan bir olgudur ve özellikle istihdam ve tüketim gibi önemli ekonomik faaliyetleri kolaylaştırmaktadır ve sosyal etkileşimi etkilemektedir (Whitmeyer, 2000: 204).

Olumlu bir itibar hem bireyler hem de örgütler için faydalı olabilmektedir. Genel olarak başkalarının kolektif algılarından oluşan ve bir kimlik olarak anlaşılan itibar, bireylerin ve örgütlerin eylemlerine dayanmaktadır. Bununla birlikte, itibarın asıl gelişmesine yol açan bu eylemlerin daha büyük gruplara rapor edilmesi ve daha sonra bu eylemlerin bu gruplar içindeki bireyler tarafından tartışılmasıdır. Çünkü, bu eylemleri değerlendirecek izleyiciler olmadan itibarın üzerinde ortak bir anlaşılmaya varılması mümkün değildir.

\section{Kişisel İtibarın Gelişimi ve Aktarımının Teorik Temelleri}

Kişisel itibar kavramına temel oluşturabilecek teorilerin çoğu sosyal psikoloji alanından gelmektedir. Bahsi geçen kavramın gelişimine dayanak oluşturan teoriler aşağıda sırasıyla verilmektedir.

Sinyal Teorisi: Gönderici-mesaj-alıcı iletişim modeline dayanan sinyal teorisinde gönderici alııının bilmediği bilgiye sahip olmaktadır ve gönderici alıııya bilgiyi göndermeye (sinyal) çalışmaktadır. Bu sinyal, alıcının algısıyla ilgilidir ve göndericinin yolladığı sinyal alıcı tarafından değerlendirilmektedir. Böylelikle bilgi asimetrisi azaltılmaktadır (Spence, 2002: 434). Sinyal teorisi, bireylerin bilgi iletmek veya inançları değiştirmek için diğer bireylere sinyal vermesini önermektedir. Bu teori, bireylerin başkalarına bilgi aktarma veya başkalarının inançlarını değiştirme girişimlerinde sinyal verdiğini belirtmektedir (Zinko vd., 2010: 4).

İtibar diğerlerini etkileyen gözlemlenebilir ve değiştirilebilir özellikleri temsil ettiği için sinyal olarak görülmektedir. İlk izlenimlerin itibar oluşturmada önemli bir rolü bulunmaktadır. Bireyler bir örgüte ilk girdiklerinde bu bireyler hakkında çok az şey bilinmektedir. İzleyicilerin bu bireylerin gelecekteki eylemlerini tahmin edebilmeleri için bireylerin izleyicilerine bilgi (sinyal) sunmaları onların itibarlarının temelini oluşturmaktadır (Baiman, 1991: 356; Ferris vd., 1999: 406). Özellikle insan sermayesi, sinyal teorisi perspektifinden incelendiğinde, sahiplerine anında güvenilirlik ve statü sağlamaktadır. Birey, bireysel özelliklerine dayalı olarak başkalarına sinyal göndermektedir. Ayrıca bireyin gerçek yeteneklerine ilişkin bilgisine ek olarak eğitim gibi çeşitli bireysel niteliklere de değer verilmektedir. Örneğin, eğitim önemli bir sinyal sağlayıcıdır, ancak bir sinyal olarak eğitimin değeri, bir örgütte üst düzeylerde dikkate alınırsa etkisi büyük ölçüde artmaktadır (Hall vd., 2004: 520).

Sosyal Yayılım Teorisi: Sosyal yayılım kavramının "sosyal" ifadesi, yayılım sürecinin sosyal bir bağlamda gerçekleştiğini, başka bir deyişle, iki veya daha fazla bireyin birbiriyle temas halinde olduğunu ifade etmektedir. Sosyal yayılım ise, bir grup birey arasında duygusal ve davranışsal tepkilerin kendiliğinden yayılmasını vurgulamaktadır (Yukl, 1998: 307). Diğer bir ifadeyle, sosyal yayılım, duygusal ve davranışsal tepkilerin A kişisinden B kişisine yayılması olarak tanımlanmaktadır (Levy ve Nail, 1993: 271). Sosyal yayılım; duygusal ve davranışsal yayılımı bünyesinde taşımaktadır. Davranışsal yayılım, dışarıdan görünen davranışlar 
bir kişiden diğerine açıkça aktarıldığında mevcut olabilmektedir. Duygusal yayılım ise duygusal bileşenler ve özellikle ruh halleri bireyler arasında aktarıldı̆ıında kendisini göstermektedir (Totterdell vd., 1998: 1505).

Sosyal yayılım; fikirlerin, tutumların, inançların ve davranışların benimsenmesini ve yayılmasını sağlamak için yaygın olarak kullanılan teorik bir mercektir. Bu nedenle, sosyal yayılım genellikle grup üyeleri arasında paylaşılan bir dizi inançla sonuçlanmaktadır (Anglin vd., 2018: 395). Teori, kişisel itibar bağlamında değerlendirildiğinde sosyal yayılım sadece itibarın yapısını değil, aynı zamanda itibarın transferini de açıklamaya yardımcı olmaktadır. İtibar, dedikodu gibi gayri resmi konuşmalarla da aktarılabilen ve sosyal olarak inşa edilen bir kavram olduğundan, bireyler arasında etkileşim esastır. Sosyal yayılım teorisi bu etkileşimi açıklamaktadır. Ayrıca, bir başkasının itibarı üzerinde hemfikir olan bir grup, itibar oluşturan bireyle fiilen doğrudan temas halinde olmasa bile itibarın paylaşıldığı ve sosyal olarak inşa edildiği gerçeği bulunmaktadır (Zinko vd., 2007: 172).

Sosyal Karşılaştırma Teorisi: Illk olarak Festinger (1954) tarafından önerilen sosyal karşılaştırma teorisi, bireylerin kendilerini başkalarıyla karşılaştırarak kendi fikirlerini ve yeteneklerini değerlendirmek için öz değerlendirme yapmanın önemli bir yol olduğunu öne sürmektedir. Öz değerlendirme sürecinde, öncelikle nesnel bilgi araçları aranmaktadır. Ancak bu bilginin yokluğunda bireyler kendilerini başkalarıyla karşılaştırmaya çalışmaktadırlar (Heo vd., 2020: 293). Karşılaştırma hedefi seçimi ile ilgili olarak, bireyler genel olarak kendilerini kendilerinden daha üstün veya daha iyi olarak algıladıkları bireylerle karşılaştırmayı tercih etmektedirler (yani, yukarı doğru karşılaştırma) (Gerber vd., 2018: 6-7). Sosyal karşılaştırma kapsamında yer alan yukarıya doğru karşılaştırma kendini iyileştirme, kendini geliştirme ve kendini değerlendirme arzularını barındırmaktadır. Kendini iyileştirme güdüsü olan bireyler, yukarı doğru karşılaştırma hedefinden bir şeyler öğrenmek ya da ondan ilham almak için kendilerini başkalarıyla karşılaştırmayı seçmektedirler. Kendini geliştirme güdüsü olan bireyler ise kendilerini bir üst gruba ait olma algısı oluşturmak ve böylece kişisel değer duygularını geliştirmek için yukarı yönlü bir karşılaştırma hedefiyle kıyaslamaktadırlar. Son olarak, öz değerlendirme güdüsü olan bireyler, kendilerini doğru bir şekilde değerlendirebilecekleri daha yararlı bilgiler elde etmek için yukarıya doğru karşılaştırma yapmaktadırlar (Eddleston, 2009: 89; Foley vd., 2016: 147; Choi, 2020: 652-653).

Öz Düzenleme Teorisi: Öz düzenleme, bireylerin hem tutumlarını, duygularını hem de davranışlarını hedef alan ve bireyin kendi kendini yönlendiren bir sürecin yanı sıra bireyin kendi hedeflerine hizmet etmek için ortaya koyduğu çabadır (Boekaerts, 2010: 71). Öz düzenleme, kasıtlı veya farkında olmadan dikkat, düşünce, duygu ve davranışların öz kontrolünü içermektedir. Bu nedenle, öz-düzenleme yalnızca davranışın düzenlenmesini değil aynı zamanda davranışı gerçekleştirmeden önce, gerçekleştirme sırasında ve sonrasında bilişlerin ve duyguların düzenlenmesini de içermektedir (Karoly, 1993: 42-45; Zimmerman, 2000: 14). Öz-düzenleme araştırmalarının önemli bir kısmı, bireylerin görev performansını artırmak için hedeflerin en iyi şekilde nasıl kullanılacağına odaklanmaktadır (Locke ve Latham, 2002: 708).

Bireyler değerli bir hedefe (yani yüksek dışsal motivasyona) ulaşmak için ve görevin kalıcılığını ve performansını sağlamak için kendi kendini (öz) düzenlemeye ihtiyaç duymaktadırlar (Van Hooft vd., 2013: 9). Hedef belirleme ve daha sonra bu hedeflere ulaşmak için çabalama süreci olan öz-düzenleme teorisi, bireyin bir standardı karşılama veya elde etme çabalarında bir süreci başlatmayı, durdurmayı, değiştirmeyi gerektirmektedir (McCrory vd., 2013: 137). Ardından, mevcut koşulların algılanması ve bu koşulların bazı standartlarla karşılaştırılması gerekmektedir. Standart; sosyal normlar, bireysel hedefler ve başkalarının beklentileri gibi şeylerin nasıl olması gerektiğine dair bir kavramdır. Bireyin mevcut durumu ile daha arzu edilen bir potansiyel durum arasında tutarsızlıklar olduğunda birey, standarda ulaşmaya yönelik bir davranışta bulunmaktadır. Ancak hedef arayışının gerçekleşebilmesi için mevcut duruma ilişkin geri bildirimlerin de mevcut olması gerekmektedir. Mevcut performans seviyesi hakkında bilgi olmadan, mevcut durumu hedef durumla karşılaştırmak imkânsız hale gelmektedir. Bu da tutarsızlıkları ortaya çıkaramamaya neden olmaktadır ve boşluğu azaltmaya yönelik sistematik davranışsal veya bilişsel ayarlamayı engellemektedir. Standart karşılanmadıysa birey, süreci tekrarlamakta ve standart karşılanana kadar ilerlemeyi izleyemeye devam etmektedir. Tutarsızlık azaldığında, döngü sona ermektedir (Howe vd., 2013: 2). 
Zinko vd. (2007: 170), örgütlerde itibar inşasında yer alan davranışsal eylemi modellemek için özdüzenleme teorisine bir öneride bulunmaktadırlar. Bir birey davranışını kabul edilmiş bir standardı karşılayacak şekilde düzenlemek yerine, itibar oluşturan bireyin davranış normlarının veya davranış standardının ne olduğu ortaya koyması gerekmektedir. Daha sonra bireyin belirli davranışları iletmek için tasarlanmış şekilde bu standarttan sapan davranışları sergilemesi beklenmektedir. Ardından, göze çarpan davranışların ve izleyiciler tarafından dikkat çeken bu davranışsal normlar sapmayı oluşturmakta ve itibar gelişimi ile sonuçlanan bilişsel işlemeyi başlatmaktadır.

Sosyal Bilgiyi işleme Teorisi: Sosyal bilgi işleme teorisi, bireylerin başkalarının eylemlerini nasıl algıladıklarını anlamak için sosyal dünyayla ilgili olarak kullandıkları tüm zihinsel süreçleri göz önünde bulundurmaları gerektiği temel öncülünden yola çıkmaktadır. Bu öncül, kişinin bireysel davranışının meydana gelmesi için uyum sağladığı sosyal çevreyi inceleyerek öğrenilebileceği sonucuna götürmektedir (Salancik ve Pfeffer, 1978: 226). Bu teorinin sağladığı fayda ise bireylerin etkileşimlerini, çalışanların iş tutumunu ve davranışlarını etkileyen bilgiler sağlayabilmesidir. Böylece sosyal bilgiyi işleme teorisi, bireylerin iş ortamlarını yorumlamak ve kendi ihtiyaçlarını anlamak için bireylerin işyerinde mevcut olan sosyal bilgileri işlediklerini ve buna göre davranışlarını düzenlediklerini iddia etmektedir (Yang vd., 2019: 157). Örneğin, bireylerin genellikle çalışma ortamını yorumlamak ve ardından eylem kararları almak için sosyal normlara ve beklentilere dayanan bir dizi ipucu almaktadırlar (Frazier ve Bowler, 2012: 845-846). Kişinin ipuçlarına davranışsal tepkisi, bu ipuçlarının duyum ve algı yoluyla kodlanmasıyla başlayan zihinsel süreçlerin bir işlevi olarak ortaya çıkmaktadır. İpuçlarının yorumlanması, ipuçlarının alındığı ortama bağlı olmaktadır. Uyaran ipuçları bir kez zihine tanıtıldığında, kişi bellekten bir veya daha fazla olası davranışsal tepki almaktadır. İşlemenin son adımı ise değerlendirme ve karar vermedir. Burada, bireyin durumu nasıl değerlendirdiği ve nasıl yanıt vereceğine karar verdiği hususu bulunmaktadır (Chen vd., 2013: 1621; Boekhorst, 2015: 245-246).

Sosyal bilgi işleme teorisine göre, öncelikle itibar inşa etmek isteyen birey ile izleyicileri sosyal etkileşime girmektedir. Oluşan bu sosyal etkileşim sayesinde itibar oluşturmak isteyen bireyler, mensup oldukları grupta olumlu sapmalar ortaya koymaktadırlar. Ardından izleyiciler, birey tarafından verilen tutarlı sosyal ipuçlarını anlamlandırmakta, yorumlamakta ve deneyimlemektedirler (Rego vd., 2017: 6). Bu durum, bireylerin belirli itibarlar inşa etme girişimlerinde belirli şekillerde davranabileceklerini göstermektedir. İtibar oluşturmaya çalışan bireyin eylemlerini açıklamak için diğer bireylerin sosyal bilgi işlemeyi kullanacağı anlayışına dayanmaktadır. Bu eylemler hem bireyin hem de izleyicinin etkileşimde bulunduğu ve faaliyet gösterdiği bağlamsal zemin ışı̆̆ında yorumlanmaktadır ve belirli bir sosyal mesajı iletmek için kullanılmaktadır (Zinko vd., 2007: 171).

\section{Kişisel İtibarın Öncülleri}

Kişisel itibarın oluşturulması ve sürdürülmesi birtakım öncüllere bağlıdır. Aşağıdaki bölüm bu yönleri ele almaktadır.

Kişilerarası Güven: Kişilerarası güven, bir birey veya grubun başka bir birey ya da grubun sözüne veya yazılı beyanına güvenebilme beklentisidir (Rotter, 1971: 444). İlgili kavrama ilişkin bir başka tanım da, "bir bireyin başka bir bireyin adil, etik ve öngörülebilir bir şekilde hareket etmesine yönelik sahip olduğu beklenti düzeyidir" şeklinde yapılabilir (Thomas vd., 2009: 288). Kişilerarası güven, bireyin bir başkasının sözlerine, eylemlerine ve kararlarına ne kadar güvendiği ve bunlara göre hareket etmeye istekli olduğu ölçüde ortaya çıkmaktadır (McAllister, 1995: 25). Kişilerarası güven bilişsel ve duygusal temele sahiptir. Güvenin rasyonel temeli olan bilişsel güven, güvenilen bireyin kimlik bilgileri, yetkinliği, uzmanlığı ve güvenilirliği ile ilgilidir. Bu sayede bireyler, kime ve hangi koşullar altında güveneceklerini seçmektedirler (Moye ve Henkin, 2006: 103). Duygusal güven ise her iki taraf arasında duygusal bir bağ olduğunda ortaya çıkmaktadır ve güvenilen kişi, güvenen tarafla olan ilişkiyi sürdürmek için güveni yerine getirmeye motive olmaktadır (Chai ve Dibb, 2013: 63).

Güven, toplumlar için de değerli bir operasyonel kaynaktır ve çoğu işbirlikçi ilişkiyi bir arada tutan yapıştırıcı görevi vardır (Limerick ve Cunnington, 1993: 129). Dolayısıyla, bir bireyin diğer grup üyeleriyle işbirliği yapma veya düzgün etkileşimleri kolaylaştırma olasılığını arttıran güvenilirliktir (Jazaieri vd., 2019: 
965). İtibar ve güven arasında önemli bir bağlantı bulunmaktadır ve bireyin yerleşik bir itibara sahip olması, diğer bireylerin onun gelecekte sürekli olarak böyle davranacağına güvenme eğiliminde olduklarını ve bunun da öngörülebilirlik hissine yol açabileceğini göstermektedir (Ranft vd., 2006: 280). Bu sebeple, güvene dayalı iş iliş̧kileri, öncelikle kişisel itibarın karakter boyutunu yönlendirebilmektedir (Laird vd., 2012: 574). Yani, itibarın ortaya çıkardığı etkilerin değeri, sosyal etkileşimlerde ortaya çıkan güven derecesinden kaynaklanmaktadır (Zinko vd., 2007: 186). Gowler ve Legge'ye (1989) göre diğer bireylerde güven oluşturan bir birey, olumlu kişisel itibar ile sorumlu davranış algısı oluşturmaktadır. Benzer şekilde bazı araştırmacılara göre bireyler, dürüstlük ve adaletli davranışlar göstererek itibarı oluşturabileceklerini savunmaktadırlar (Becker, 1998; Schlenker vd., 2008). Gerçekten de güvenilir olma itibarı, etkili iş ilişkilerinin temeli yapmaktadır ve güvenilir kişiler daha fazla güvenilirliğe sahip olarak değerlendirilmektedir (Laird vd., 2013: 672). Bu nedenle güvenilirlik, itibarın nasıl geliştirildiğine odaklanmaktadır. Ayrıca, bir bireyin itibarı ne kadar iyi kurulmuş ve tanımlanmışsa, diğerlerinin bireyin belirli bir şekilde davranacağına güvenmesi o kadar olası görülmektedir (Ferris vd., 2014: 262).

Politik Beceri: Mintzberg (1983), "politik beceri" kavramını, bireylerin örgütsel yaşamın politik arenalarında etkili olmaları için ihtiyaç duydukları kişisel bir özelliği ifade etmek için türetmiştir. Politik beceri, başkalarının duygularına karşı resmi gücü kullanma, onların enerjilerini nereye konsantre edeceğini bilme, neyin mümkün olduğunu hissetme ve gerekli her şeyi organize etme yeteneği olarak tanımlanmaktadır (Mintzberg, 1983: 26). Bireyin davranışının başkalarını etkilemek için farklı ve değişen durumsal ihtiyaçlara göre ayarlama yeteneği ile karakterize olan politik becerinin dört temel boyutu bulunmaktadır. Bunlar; (1) samimi olduğunuzu iletme yeteneği, (2) başkalarını etkileme yeteneği, (3) sosyal durumları "okuma" yeteneği ve (4) etkili kişilerarası ağlar oluşturma yeteneğidir (Ferris vd., 2005: 129; Zinko, 2013: 1752). Politik olarak yetenekli bireyler, sosyal etkileşimler ve bağlamlar hakkında derin bir anlayışa ve sosyal zekâya sahiptir. Bu, bireylerin davranışlarını etkileşimde bulunabilecekleri farklı bileşenlere uyacak şekilde ayarlamalarına olanak tanımaktadır. Bu tamamlayıcı sosyal yeterlilikler seti, geniş bir iletişim ağının desteğine ve güvenine ilham vermektedir. Böylece izleyicilerin tutumsal ve davranışsal tepkilerini etkilemektedir (Laird vd., 2013: 662). Politik becerinin örgütlerdeki bireyler üzerinde kontrol ve keskin bir anlayıs geliștirmesinden kaynaklanan kişisel güvenlik ve özgüven duygusu aşılamaktadır. Bu his, sadece bireyin diğerlerini etkileme girişimlerini göstermelerine değil, aynı zamanda süreci başarılı bir şekilde yürütmesine de izin vermektedir (Ferris vd., 2005: 127-128).

Politik beceri ile itibar arasındaki ilişki, itibar inşa etmeye veya sürdürmeye çalışan bireylerin elde etmek istedikleri itibarla tutarlı bir şekilde çevrelerindeki bireyleri etkileyebilmeleri gerektiği düşünüldüğünde, kolayca ortaya çıkmaktadır (Zinko, 2013: 1753-1754). Kişisel itibarların kendi kendine gerçekleşmediği, bireylerin bilinçli ve kasıtlı davranışlarıyla geliştirilip yönetilebileceği konusunda genel bir anlayış bulunmaktadır. Bu anlayış, politik beceri yapısı ve uyarlanabilir öz-düzenleme teorisi ile açıklanmaktadır (Laird vd., 2013: 664). Bireyler, başkalarının gözünde arzu ettikleri itibarı elde etmek için izlenimleri yönetmeye motive olmaktadırlar (Ferris vd., 2014: 256). Bu sebeple, bireyler itibar sinyallerini kendi çıkarları doğrultusunda manipüle etmek için politik manevralara girebilmektedirler (Laird vd., 2012: 559). Politik beceri, bireylerin çevrelerindekileri etkilemesine izin verdiği için politik becerileri yüksek olanlar, bir izleyiciye söylenecek mesajı daha iyi oluşturabilmektedirler. Yani, sosyal zekâları, kişilerarası etkiye karşı esnek, uyumlu yaklaşımları olan bu bireyler, istenen imajı geliştirmek için davranışsal süreçleri nasıl göstereceklerini tam olarak bilmektedirler (Laird vd., 2013: 663). Böylelikle bu bireyler, proaktif ağ oluşturma faaliyetleri ve duruma uygun etki taktiklerinin kullanımı yoluyla topluma olumlu imajlar oluşturan sinyalleri ilettikleri için kişisel itibarlarını oluşturmada etkilidirler. Bu etki sayesinde, politik olarak yetenekli bireyler tarafından iletilen kişisel itibar sinyallerinin, sosyal ağlarında etkili kişilerle kurulan bağlantılar nedeniyle hızla yayılması muhtemeldir (Laird vd., 2012: 560). Liu vd. (2007) konuya ilişkin yapmış oldukları araştırmada, politik olarak yüksek beceriye sahip bireylerin olumlu itibar geliştirme olasılıklarının daha yüksek olduğu bulgusu yukarıda ifade edilen teorik açıklamaları destekler niteliktedir.

Insan Sermayesi: Örgütlerde olumlu bir itibar geliştirmek için bireyler, kendilerine özgün becerilere veya uzmanlığa intiyaç duymaktadırlar. İnsan sermayesi teorisi, bireylerin eğitimsel, deneyimsel ve başarılar yoluyla bilgi, beceri ve yeterlilik kazanarak kendileri için değer yarattıklarını ileri sürmektedir (Goldin, 2016: 
1). Örneğin yaş, deneyim için önemli bir öncüldür, dolayısıyla daha ileri yaştaki bireylerin daha deneyimli olduğuna inanılmaktadır. Deneyim ve eğitim, bireyin itibarının yaştan etkilenen bileşenleri olarak görülmektedir. Ancak ilişki her zaman doğrusal değildir. Örneğin, kariyerinin başlangıcında, Steve Jobs'ın itibarının aldığı eğitim ya da deneyimle doğru orantılı gitmediği bilinmektedir. Buna karşılık, eski IBM CEO'su John Akers'ın yıllar içinde ilerleyen yaşı ile deneyimi doğrusal bir birleşimini temsil eden bir itibarı bulunmaktadır.

İnsan sermayesi sinyal teorisi bakış açısından ele alındığında, bireylerin değer yargıları itibar üzerinde güçlü etkiler oluşturabilmektedir. Bireyin gerçek yetenekleri hakkındaki bilgi yerine eğitim gibi çeşitli bireysel niteliklere değer verilmektedir. Yani, bireylerin gözlemlenebilir özellikleri kişisel deneyimler ışı̆̆ında değerlendirilmektedir. Bu nedenle, bu demografik özellikler bireyin itibarını da etkilemektedir (Hall vd., 2004: 519-520). Diğer yandan, uzmanlık alanı olarak görülen insan sermayesi itibar bağlamında ele alındığında, bireylerin bir örgütteki rollerini yüksek beceri ve yetenekle yerine getirdiklerinde beklentilerin ötesinde üstünlük yaratabilmektedirler. Bu durum, izleyicilerin kendi aralarında bir bireye ait beceri ve yeteneklerin sohbet konusu olmasını sağlayarak zihinlerde itibar algısı oluşturabilmektedir (Zinko vd., 2012: 159).

İlgilenen İzleyiciler: İzleyiciler, var olan normlardan sapan konuları ilginç buldukları için tartışmaktadırlar. Bir izleyici tarafından yapılan bu tartışmalar ve değerlendirmeler, genellikle dedikodu yoluyla gerçekleşmektedir (Baumeister vd., 2004: 119-120). Örgütlerdeki tüm iletişimin üçte ikisini kapsayan dedikodu, genellikle bir örgüt için zararlı olarak görülmektedir. Ancak itibarın pekişmesi için böyle bir tartışma gereklidir. İtibarın tanımı gereği, bir itibarın ortaya çıkması için bir izleyici tarafından anlaşmaya varılması gerekir. Kitlenin ilgisi, normlardan sapma düzeyine bağı olarak değişse de itibar, izleyicinin bir birey hakkında daha fazla bilgi edinme arzusu temelinde de yayılabilmektedir. Birey hakkında en iyi bilgiyi bilmek neredeyse imkânsız olduğundan, onun yerine itibar sıklıkla kullanılmaktadır (Hoekstra, 2011: 161). Vekalet teorisi, izleyicilerin bilinçli kararlar almak için bir konu hakkında bilgi arayacaklarını belirtmektedir. İzleyiciler, konuya belli bir düzeyde öngörülebilirlik kattıkları için itibarlar bu gerekliliği karşılamaktadır (Zinko ve Rubin, 2015: 227). Örgüte yeni bir çalışan veya yönetici katıldığında, çalışanlar genellikle yeni gelen birey hakkında bilgi edinmek istemektedirler. Bu da çalışanların birey hakkında bilinebilecek sapmalarla ilgilenmelerine sebep olmaktadır. Örneğin, bir örgüt New York'ta bulunuyorsa, örgüte yeni katılan bireyin İngilizce konuşması, normlardan sapmadığı için diğerleri nezdinde ilgi çekici olmayabilir. Öte yandan, bu bireyin beş yabancı dil konuşması, bir sapmaya atıfta bulunacaktır ve bu da muhtemelen mevcut çalışanlar arasında tartışılacaktır. Bununla birlikte, ilgili örgüt Birleşmiş Milletler'de ise beş yabancı dilden bahsetmek olağandışı olmayacaktır ve bu nedenle izleyiciler arasında tartışma konusu olarak görülmeyecektir (Zinko vd., 2017c: 92).

İstekli Destekçiler: Bireyler genellikle iki nedenden biri için bir örgütte başkalarını tartışmaktadırlar. Birincisi, bu bireylerin konuyu ilginç bulmalarıdır. Bu ilgi genel olarak, hakkında konuşulan bireyin var olan normları ihlal etmesiyle ortaya çıkmaktadır. Bireylerin bir örgütte başkasını ya da başkalarını tartışmalarının ikinci nedeni ise bu bireylerin kendi çıkarlarına fayda getireceğine dair inançlarıdır (Farley, 2011: 574-575). Nitekim, normlardan sapan biriyle ilişki kuran bir birey, bu sapmayı alenen ortaya çıkararak bu durumu kendi yararına kullanabilir. Normlardan sapan birinin sahip olduğu itibar, bireylerin itibarlı bir kişiyle ilişkilerini gösterme veya vurgulama eğiliminde olduklarını göstermektedir. Bu durum bireyin elde ettiği itibarın getireceği faydalar, diğerlerinin de faydalanmasına neden olmaktadır (Zinko vd., 2017c: 93).

Normlardan sapan bireyin eylemlerine tanık olan izleyiciler, bu bireyin kendi konumunu ya da statüsünü artırmak isteyebilirler. Dolayısıyla izleyiciler, bireyin normlardan sapan davranışlarını tekrarlamaları için bireyi motive etmeye çalışabilirler. Eğer bireyin gösterdiği sapmalar, örgütün ilgisini çekecek kadar büyük değilse, bu sapmaları bir izleyici kitlesinin tanıtmasına intiyaç duyulabilir. Yani, bu kişinin ağındaki bireyler, bu kişiyi örgüte tanıtma kaynağı olarak kullanılabilirler (Wanberg vd., 2000: 491-494). Ayrıca, izleyiciler başka bir bireye kefil olmaya ne kadar istekli olurlarsa, bu bireyin itibarının ağlar arasında yayılma olasılığı o kadar artmaktadır. Böylece bu gönüllü destekçilerin, bireye ilişkin normların belirli tekrarlanan sapmaları hakkında örgüte bilgi vermesi beklenmektedir. Yani, ilgili bireyin örgütteki istenen pozisyonda mükemmel olacağını düşündüren davranışsal ayrıntılar yansıtılmaktadır. Bu bilgiler, örgüte mensup olan izleyiciler tarafından aktarılacağı için bireye ait bilgiler büyük olasılıkla gerçek olarak alınacaktır (Zinko vd., 2017c: 93). 


\section{Kişisel İtibarı Oluşturmak}

Bir bireyin itibarının diğer bireyler topluluğu içinde nasıl geliştiği ve yayıldığı oldukça önemlidir. Bu önem dikkate alındığında itibar, bir bireyin eylemleri tarafından oluşturulmasından ziyade itibar, bir izleyici grubu tarafından bu eylemlerin değerlendirilmesiyle oluşmaktadır (Ferris vd., 2003). Bir bireyin itibar bilgisi, dağıtıcı ve söylemsel olmak üzere iki biçimde kavramsallaştırılmaktadır. Dağıtım itibarı, grup üyeleri tarafından oluşan sosyal ağdaki üyelerce paylaşılan ve bu üyelerin bir birey hakkında aldıkları kararları ifade etmektedir. Dağıtım itibarı; referanslar, kişisel öneriler, akran değerlendirmeleri aracılığıyla grup üyesi hakkındaki bilgilerden oluşmaktadır. Söylemsel itibar bilgisi ise grup üyeleri arasında aktif iletişimle ortaya çıkmaktadır. Söylemsel itibar, çeşitli sosyal uygulamalar, alay etme, bireylerin hoşlandıkları bireyler hakkındaki sohbet ve dedikodu aracılığıyla biçimlenmektedir (Jazaieri vd., 2019: 965). Örneğin, bir birey örgütte bulunmadan önce bir izlenim oluşturma avantajına sahiptir. Önceden oluşturulacak ilk izlenim, bireyin eylemleriyle ilgili bir hale etkisi yaratarak izleyicilerin dikkatini etkileyecektir. Öncelikle izleyiciler, bireyin neyle tanındığına odaklanacaklardır. Bu da birey hakkındaki söylemleri artıracaktır. Bu süreç, bireye yeni bir çevreye uyum sağlaması ve itibar inşa etmesi için zaman vererek bireye avantaj sağlayacaktır (Zinko vd., 2012: 162).

İtibar gözlemlenebilir eylemlere dayanmaktadır. Bu eylemler, izleyicilerin bunları başkalarına rapor edecek kadar ilginç bulacağı şekilde öne çıkmalıdır. İzleyiciler bir olayı değerlendirirken, bireyin geçmiş bilgilerine dayanarak o olayla ilgili öngörü ve varsayımlarda bulunmaktadırlar. Bu durum, gözlemlenen bireyin karakteristiği olan davranışlardan türeyen rollere ve beklenen normlara dayanmaktadır (Zinko vd., 2007: 183). İzleyiciler, mensup oldukları örgütün normlarını ve değerlerini zaman içinde içselleştirmektedirler. Ardından bu izleyiciler, örgütteki belirli bireyleri nereye yerleştirilmek istediklerine karar vermektedirler. Bu sürecin alt zemininde yer alan sosyal sınıflandırma ve karşılaştırma teorileri (Tajfel ve Turner, 1979) sayesinde, izleyiciler çevrelerindeki bireyleri belirli kategorilere yerleştirmektedirler. Sınıflandırma, benzer algılanan özelliklere dayanmakta ve örgütteki herkes bir dizi özelliğe sahip olacağından, bu bireyleri belirli kategorilere ayırmak için üyeler arasındaki benzerlikler aranmaktadır (Ashforth ve Mael, 1989: 20; Bartels vd., 2007: 173). Bu benzerlikler, bir gruba özgü olduğu için gruptaki bir bireyin mevcut davranış sapmalarını yansıtacak şekilde normlardan olumlu sapmalar yapması gerekmektedir. İzleyiciler bu tekrarlanan sapmaları fark ettikçe bireyin eylemleri artık mevcut kategoriyle tutarlı olmadığı için kafa karışıklığı yaratacaktır. Bu nedenle izleyiciler, söz konusu bireyi zihinsel olarak uygun kategoriye taşıyarak kafa karışıklıklarını çözmeye çalışmaktadırlar. İzleyicilerin, bireyi farklı bir grupta yeniden sınıflandırabilmeleri (yani, norm ile birey arasındaki ilişkiyi çözebilirse) mümkündür. Birey tarafından tekrarlanan sapmaların norm olarak kabul edildiği bir grupta, bireyin gelecekteki davranışları bir kez daha öngörülebilir olmaktadır ve bireyin davranışları diğerlerine anlamlı gelmektedir (Zinko vd., 2017c: 93-94).

Bireyler, izleyicilerini etkileme eğilimindedir. Bu nedenle bireyler, başkalarının kendi oluşturdukları izlenimleri yönetmek için aktif çabalarla itibarlarını geliştirmek ve sürdürmek istemektedirler (Ranft vd., 2006: 280). Bu çerçeveden bakıldığında sıradan olaylar başkaları tarafından nadiren tartışıldığı için izleyicilerin kolektif algıları, onların ilginç veya olağandışı bulduğu eylemlere dayanmaktadır (Zinko vd., 2017c: 88). Herkes yüksek düzeyde performans gösteriyorsa, bunu yapan her birey ortalamanın en iyisi olarak görülmemektedir. Yani, bireyin örgüt normlarından sapma göstermesi gerekmektedir. Bu sapmalar, yüksek performans veya en iyi olarak bilinmek olabilir (Zinko vd., 2007: 183-184). Bütünsel bir bakış açısıyla incelendiğinde, itibarın inşa edilmesinde iki boyut dikkate alınmaktadır. Bunlar; sapmanın seviyesi ve sapmadaki sıklıktır. Belirli normlardaki sapmaların seviyesi ve sıklığı, sadece bir itibarın gelişsip gelişmeyeceğini değil, aynı zamanda ne tür bir itibarın ortaya çıkabileceğini de belirlemektedir. Yüksek sapmalar, bu sapmaların oluş sıklığı veya bunların her ikisi de olduğunda izleyicilerin kolektif algılarında oluşumlar başlamaktadır. Bu sapmalar, grubun normlarına ve mevcut konunun beklenen durumuna dayanmaktadır. Çoğu birey, normlardan küçük boyutlarda sapmaktadır. Bu sapmalar, ortalama her çalışanda görülen davranışlardır ve bireyler bu sapmalarla tanınmamaktadır. Bununla birlikte, bir eylemin tek başına tanınması, bir itibar yaratmak için yeterli değildir. Bu durum, şöhret olarak bilinmektedir. Şöhret, tekrarlanmadığı ve gelecekteki davranışları tahmin etme durumu olmadığı için itibarla eş kavram olarak görülmemektedir. İtibar kavramında olduğu gibi şöhret bir konu üzerine kurulur ancak şöhret, itibar gibi geleceğin öngörülmesinden yoksundur (Milewicz ve 
Herbig, 1994: 41). Normlardan herhangi bir yüksek sapma fark edilirse ve bu olay sadece bir defa gerçekleşiyorsa burada itibardan söz edilmez. İtibardan söz edilebilmesi için davranışın herhangi bir düzenlilikle gerçekleşmesi beklenmektedir. Yani itibar, bireyin bir özelliğinin zaman içindeki tutarlıı̆ı̆ın tahminini yansıtmalıdır. Bir bireyin eylemlerini değerlendiren izleyiciler, bu eylemlerin arkasındaki nedenleri daha iyi anlamak için genellikle o bireyin geçmiş deneyimlerini kullanmaktadırlar. İzleyici algıları geçmişe bağlanmaktadır ve normdan büyük sapmalar sayesinde hatırlanmaktadır. Birey geçmişten gelen belirli bir olaya ya da özelliğe bağlıysa ve bu olay ya da özellik, izleyicilerin zihninde bireyin bir parçası olarak kabul edilirse, söz konusu bireyin gözlemlenen diğer tavırları, bu olaydan ya da özellikten etkilenmektedir (Zinko vd., 2017c: 89-90).

İtibar ve güven bağlantısı önemlidir ve bir bireyin yerleşik itibarı olduğunda, izleyicilerin bu bireye ilişkin gelecekte de tutarlı davranacağına güvenme eğilimlerini olduğunu göstermektedir (Ranft vd., 2006: 280). Diğer bir deyişle, itibar inşa etme ve sürdürebilirliğini sağlamada, "güven" kritik rol oynamaktadır. Çünkü, güven ile ilgili öznel olasılıklar oluşmaktadır. İtibar bilgisinin iletilmesi ve güven verilmesi, daha küçük sosyal sistemlerde (veya örgütlerde) gayri resmi yollarla gerçekleşebilmektedir (Whitmeyer, 2000: 189-190). Bu gayri resmi yollardan birinin dedikodu olduğunu ifade eden Zinko vd., dedikodunun itibarı geliştirip yayılmasını sağlayan birincil kaynak olduğu fikrini araştırmaktadırlar. Toplumsal yaşamda olumsuz bir yapı olarak algılanan dedikodunun, kişisel itibarın yaratılmasında önemli bir rol oynayabileceğini ifade etmektedirler (Zinko vd., 2017b: 520).

\section{Kişisel İtibarın Sonuçları ve Örgütlere Sağladığı Faydalar}

Kişisel itibar kavramının sonuçlarının örgütsel anlamda irdelenmesi gerekmektedir. İşletmelerin itibardan elde ettikleri avantajlar ve itibarın tüm paydaşları etkilemesi, itibarın araçsal unsurunu yansıtırken; kişisel itibarın bireysel ihtiyaçları karşılayan bir yapısı olması ise sembolik bir düzeyi yansıtmaktadır. Bu sebeple, hem bireysel motivasyon hem de örgütsel bağlamda kişisel itibarın irdeleneceği bir kapsamın belirtilmesinde yarar görülmektedir.

İtibar, güvenilirlik işlemleri sürecinin sonucunda ortaya çıkmaktadır. İtibarlı bireyler; güvenilirlik, yetkinlik, liderlik ve saygınlık gibi belirli alanlar içinde yer almaktadır (Dunn, 2008: 1). Bu sayede, itibarlı bireylerin özellikleri, mensup oldukları örgütler üzerinde etkisi bulunmaktadır ve zaman içerisinde işletme çalışanları tarafından güven ve bağlııı duygusu oluşmaya başlamaktadır (Ranft vd., 2006: 280). Bireyler olumlu bir itibara sahip olduklarında, izleyiciler itibarlı bireylerle özdeşleşmek istemektedirler (Zinko vd., 2012: 161). Burada ifade edilen husus, itibarlı liderlerin ve izleyicilerin aynı sosyal kimliği paylaştıklarını ve kendilerini aynı grubun bir parçası olarak hissetmeleridir. Bu şekilde, liderler grup değerleri, hedefleri, normları aracılı̆̆ıyla grup üyelerini çalışmaya güdülemektedir. Diğer yandan, bir grup içerisinde grup odaklı motivasyon sağlanması ve izleyiciler tarafından bu motivasyonun paylaşılması lidere daha fazla güven ve saygı atfedildiğini göstermektedir (Van Knippenberg ve Hogg, 2003: 256). Ullrich vd. (2009: 239-242), liderlerin grubun temsilcisi olarak görünüp görünmediğine ilişkin bir ampirik çalışma yapmışlardır. Bahsi geçen çalışmada, ilgili konuya ilişkin "Yöneticim, ekip üyelerimizin sahip olduğu ortak değeri temsil etmektedir.", "Yöneticim ekibimizin iyi bir örneğidir." gibi sorularla birlikte liderin algılanan güvenirliliği konusunda bireylerin liderlerini ne derece destekleyecekleri ve liderin önemli kararlar vermeden önce izleyicilerin görüşlerini isteyip istemediğine yönelik sorular da yer almaktadır. Elde edilen bulgular, liderlerin ve izleyicilerin aynı sosyal kimliği paylaştıklarını ve kendilerini aynı grubun bir parçası olarak hissetmelerinden hareket ederek liderlerinin grubun temsilcisi olduğunu ve bu sayede, izleyiciler nezdinde liderlerin güven, saygı ve çekici olarak algılandığını ortaya koymaktadır.

İtibar hem geçmiş hem de beklenen davranışlar açısından karakterize edilmektedir. Özellikle bireyin geçmişte tanınmış etkisi ne kadar büyükse, bu bireyin bir topluluk ağı içinde özerk olarak hareket etmesi o kadar yüksek olmaktadır (Knoke, 1983: 1068). Öyleyse artan itibar, daha büyük davranışsal serbestlik, takdir yetkisi ve özerkliği beraberinde getirmektedir. Özellikle iş ortamında olumlu bir itibarın gücü, bireyin özerkliğini ve kariyer gelişimini artırmaktadır (Zinko vd., 2012: 157). Daha olumlu bir itibar geliştiren bireyler; daha meşru, yetkin ve güvenilir olarak görülmektedirler ve genel olarak daha yüksek bir statüye sahip olmanın faydalarından yararlanmaktadırlar (Hochwarter vd., 2007: 568). Örneğin Walker (2010), olumlu itibara sahip 
olan bir CEO'nun atanmasından sonra hisse senedi fiyatlarının ve çalışanların moralinin genellikle arttığını belirtmektedir.

İlgili açıklamalar ışığında, itibarın bir taraftan özerklik, güç ve kariyer başarısı gibi ödüller elde etmek için, diğer taraftan da olumlu benlik saygısı gibi bireysel ihtiyaçları karşılamak ve aidiyet duygusunu güvence altına almak için oluşturulmak istendiği görülmektedir. Bununla birlikte, kişisel itibarın faydalarından yararlanabilecek onların yalnızca bireyler olmadığı, örgütlerin de üyelerinin kişisel itibarlarını etkileme ve bunlardan yararlanma potansiyeline sahip olduğu anlaşılmaktadır.

İtibarın bir örgütte çalışan bireylerin üstlenecekleri iş sorumluluğu üzerinde etkileri bulunmaktadır. Örneğin, bir örgütte çalışan deneyimsiz bir bireyin rakibinin sergilediği davranışlar karşısında, rakibinin olumsuz bir itibara sahip olduğunu bildiğinde, olumlu davranış taktiklerini kullanma olasılığı daha yüksektir ve böylece rakibinin performansını engellemesi de mümkündür (Tinsley vd., 2002). Yapılan bir araştırmaya göre, itibar ve yararlı davranışlar arasında bir etkileşim bulunmuştur, öyle ki, iyi bir itibara sahip olan yardımsever bireyler, kötü bir itibara sahip olan yardımsever bireylerden daha fazla ödül almaktadırlar (Johnson vd., 2002). Örneğin, olumlu itibara sahip bir CEO, çalışanlara hem yeni bir yön hem de daha yüksek moral verebilmektedir. Olumlu itibara sahip bir CEO, çalışanlarının performanslarını yönlendirmek için sinyaller/ipuçları arayabilmektedir. Böylece çalışanlar, kendileri için belirlenen beklenti düzeyinde performans gösterebilmektedirler. Örneğin, Chrysler'ın CEO'su Lee Iacocca'nın itibarı, çalışanların onun etrafında toplanmalarını ve lacocca'nın şirketin beğeni görmeyen tasarımlarını öncü otomobil yeniliklerine dönüştürmesine imkân sağlamıştır (Ranft vd., 2006: 287). Buna ek olarak, bireyler kişisel itibar kazandıkça, sadece resmi değil, aynı zamanda gayri resmi otoriteden de kaynaklanabilecek güç kazanmaktadırlar (Zinko vd., 2012: 161). Benzer şekilde Hall vd. (2004), olumlu itibara sahip liderlere daha fazla güven verildiğini, daha az izlendiğini ve daha düşük hesap verebilirlik standartlarına tabi olduklarını ileri sürmüşlerdir. Diğer bir deyişle, itibar belirsizliği azaltmak için var olduğundan, izleyiciler bireyin davranışlarını tahmin edebileceklerini hissettikleri ölçüde, bireyin eylemlerini yakından izleme ihtiyacı hissetmemektedirler (Zinko vd., 2012: 161).

Örgütler, bireylerin kişisel itibarını oluşturması için önemli bir aktör olarak gösterilebilir. Bireyler gibi, örgütler de niyetlerini eylemlerle göstermektedirler. Bu çerçevede örgütler, bireyler hakkında bilgi yaymak ve bir üyenin kişisel itibarını oluşturmak veya geliştirmek için örgütsel eylemler kullanmaktadırlar. Örgüt, yeni üyenin kişisel itibarını, hedef kitlesine olumlu mesaj vermek için kullanabilir. Yani, güçlü kişisel itibara sahip bir birey örgüte girdiğinde, örgüt kendi konumunu iyileştirmek için bu itibardan yararlanmaya çalışabilir. Örneğin, olumlu bir itibara sahip bireyin bir örgüte mensup olması, izleyicilere olumlu bir sinyal gönderir. Bu olumlu sinyaller, tüketicilere ve rakiplere, örgütün pazar beklentilerine yanıt verdiğine dair bir mesaj iletebilir. Hem birey hem de örgüt için kişisel itibarın faydaları göz önünde bulundurulurken sinyalizasyon önemli bir faktör olarak görülebilir. Böylelikle sinyal vermenin hem bireylere hem de örgütlere itibar kazandırabileceği söylenebilir. Bu çerçeveden bakıldığında, örgütlerin pazara gönderdiği sinyaller sayesinde izleyicilerin gözlemlemesi ve tepki vermesi sağlanmaktadır. Örneğin, yeni atanan bir CEO'nun itibarı aracılığıyla piyasaya (ve paydaşlara) sinyal gönderilmektedir. Bir CEO'nun kişisel itibarının örgüt üzerinde anında ve uzun süreli etkisi bulunmaktadır (Ranft vd., 2006: 280-281). Örgüt yönetimi, bazen örgütün pazardaki imajını güncellemek istemektedir. Dolayısıyla, güçlü ve iyi bilinen bir itibara sahip CEO'nun işe alınmasıyla örgüt için yeni bir imaj elde edilebilmektedir. Örneğin, Burger King şirketi, 2004 yılında Greg Brenneman'ı CEO olarak işe almıştır. Yakın zamanda ilk on franchise'ından üçünün iflasını yaşamış olan bu zincir restoran şirketi için yeni bir yön başlatmak üzere işe alınan Brenneman, Burger King'in en büyük halka arzının ne olacağını düşündüğü için başarılı olmuştur (Ranft vd., 2006: 287).

Olumlu itibara sahip bireyler; daha yetkin, daha yüksek statüye sahip ve daha güvenilir olarak algılanmaktadırlar ve bunların tümü işletmeye olumlu sonuçlar sağlamaktadır (Foste ve Botero, 2012: 50). Özellikle, itibarlı CEO'ların işe alınması şirketin hisse senedi fiyatlarında kısa süreli bir artışa neden olmaktadır. Örneğin, 19 Temmuz 1996'da Al Dunlap'ın Sunbeam'in başkanı ve CEO'su olarak seçildiği gün, şirketin hisse senedi fiyatı \%49 artmıştır. Hisse senedi fiyatındaki bu artışla, Sunbeam'in piyasa değeri 500 milyon \$'a yükselmiştir. Piyasa değerindeki bu artışa yalnızca Dunlap'ın itibarı neden olmuştur (Ranft vd., 2006: 286). CEO itibarının bir örgütle birlikte algılanması ortaya güçlü bir etki çıkarmaktadır (Gaines-Ross, 2000: 366). CEO 
itibarı sayesinde hissedar değerinde belirleyici bir nitelik olduğunu ortaya koyan Burson-Marsteller araştırması CEO'lar, diğer üst düzey yöneticiler, finansal analistler, hükümet yetkilileri ve gazeteciler de dâhil olmak üzere beş önemli paydaş kategorisinden yaklaşık 1.400 etkili iş insanın katılımı ile gerçekleşmiştir. Bu araştırma, 1997'de yapılan ilk CEO itibar çalışmasıyla karşılaştırıldığında, CEO itibarının öneminin \%14 arttığını ortaya koymaktadır. Çalışmanın ortaya çıkardığı diğer bulgular ise şunlardır (Gaines-Ross, 2000: 366-367): (1) CEO itibarı, bir örgütün prestijinin \%45'ini temsil etmektedir. (2) Paydaşların \%80'i, CEO itibarının o örgütte çalışmak için iyi bir yer olarak tavsiye etmelerinde etkili olduğunu ifade etmişlerdir. (3) Paydaşların \%81'i, CEO itibarının medya denetimi altında o örgüt hakkındaki görüşlerini etkilediğini belirtmişlerdir. (4) Finans ve endüstri analistlerinin \%94'ü ise bir şirketin CEO'sunun itibarına dayalı hisse senedi önerdiklerini belirtmişlerdir. Özetle, bir örgüt güçlü bir itibara sahip bir bireyi bünyesine aldığında, o birey o örgütün nasıl algılandığının bir parçası haline gelmektedir. Böylece, bireye yönelik olumlu bir algı, örgüt algısına da aktarılabilmektedir. Örgütün bu aktarımdan elde edebileceği potansiyel fayda, sadece bireyin itibarına bağlı olabilmektedir. Yani, bireyin itibarı ne kadar güçlüyse, örgütün itibarı da o kadar güçlü hale gelebilmektedir.

CEO itibarından potansiyel olarak önemli sonuçlar ortaya çıkmaktadır. Bir CEO'nun iyi bir itibara sahip olması, müşterileri, çalışanları ve yatırımcıları örgüte çekmeye veya korumaya yardımcı olmaktadır. Bu kapsamda, yapılan araştırmalar, CEO itibarı ve kurumsal sermaye yatırımları arasında pozitif bir ilişki olduğunu vurgulamaktadırlar. Çünkü, kurumsal sermaye yatırımları, CEO'ların güvenilirliğinden ve yönetimsel başarılarından etkilenmektedirler (Jian ve Lee, 2011: 945). Diğer bir araştırmadan çıkan sonuç ise CEO itibarının etkisi örgütün toplumdaki bilinirliğini arttırırken, aynı zamanda ana paydaşlarının gözünde örgütün güvenilirliğini de arttırdığını ortaya koymaktadır (Sanchez-Marin, Baixauli-Soler, 2014: 540). Benzer şekilde, konuya ilişkin yapılan diğer araştırmalar, CEO itibarının kurumsal itibar ve kurumsal performansı etkilediğine dair bulgular ortaya koymaktadırlar (Pharoah, 2003; Ranft vd., 2006; Treadway vd., 2009; Graffin vd., 2012). Bir örgüt lideri, örgütün algılanan örgütsel prestij yönetiminde merkezi bir role sahiptir. Böylelikle liderlerin özelliklerinin liderlik ettikleri örgütler üzerinde etkisi olduğu ifade edilmektedir. Örneğin, bir krizde iç ve dış paydaşlar, liderlerin belirgin bir rol üstlenmesini beklemektedirler. Liderin örgüt sözcüsü rolünü benimsemesi durumunda, örgüt prestijinin yarısı, lider itibarından kaynaklanabilmektedir. Hizmet sektöründe yapılan bir araştırmaya göre, çalışanların tepe yöneticilerinin itibarları hakkındaki görüşlerden büyük ölçüde etkilendiklerini ve bunun da örgüt prestijine olumlu olarak yansıdığı tespit edilmiştir (Davies ve Chun, 2009: 311). Böylelikle tepe yöneticisinin itibarı paydaşlar nezdinde örgüt potansiyelini ortaya çıkaran bir sinyal görevi görmektedir (Certo, 2003). Bir örgüt güçlü bir itibara sahip birey ya da bireylerle anıldığında, bu örgütün nasıl algılandığının bir parçası haline gelmektedir ve bu da örgüte çeşitli avantajlar sağlamaktadır.

Yöneticilerin iş yeterliliğine ilişkin algıları, çalışanların değerlendirilmesinde önemli bir rol oynamaktadır. Yöneticiler, çalışanların yetkinliğini değerlendirme konusunda yeterince bilgiye sahip olamamaktadırlar. Bu nedenle, yöneticiler bir çalışanla etkileşime girerken gözlemledikleri eylemlerden bu özellikleri çıkarmaya çalışmaktadırlar. Yöneticiler bu gözlemleri, bir çalışanın işini ne kadar iyi gerçekleştirebileceğine dair ilk algıları oluşturmak için kullanmaktadırlar. Özellikle lider-üye etkileşimi bağlamı üzerinden değerlendirildiğinde, yetkinlik algıları çalışan-yönetici ilişkilerini etkilemektedir. Başlangıçta işlerinde yetkin olarak algılanan çalışanlar, yüksek lider-üye etkileşimi ilişkileri geliştirme konusunda daha büyük bir şansa sahip olmaktadırlar ve karşılığında bu ilişkilerin olumlu sonuçlarını alabilmektedirler (Graen ve Uhl-Bien, 1995). Bu nedenle, örgüte yeni giren bir çalışanın kişisel itibarın nasıl inşa edileceğini anlamasının dışında, başlangıçtaki iş yeterliliğine ilişkin algıların nasıl geliştiğini de anlaması önemlidir. İş yetkinliği farklı şekillerde yorumlansa da bu yorumların hepsi yetkin bir çalışanı, işini iyi yapan ve iş yetkinliğinin iş performansına yansıyan bir çalışan olarak tanımlamaktadır (Foste ve Botero, 2012: 51). Buna ek olarak, Kilduff ve Krackhardt (1994) tarafından yapılan bir çalışmada, kişisel itibarın iş performansının bir fonksiyonu olduğu kadar, önde gelen diğer bireylerle algılanan ilişkilerin bir fonksiyonu da olduğu ortaya konulmuştur. Özetle, kişisel itibarın örgütlere sağladığı faydalar incelendiğinde, itibarın, somut, doğrulanabilir geçmiş eylemleri yansıttığı ve itibarın genellikle istenen birden fazla sonucu olan uzun vadeli bir yatırım olarak görüldüğü dikkat çekmektedir. 


\section{Sonuç ve Değerlendirme}

İtibar, günlük yaşamda ve iş ortamlarında yoğun olarak tartışılan bir kavramdır. İtibarın makro düzeyi olan kurumsal itibar hakkında literatürde sayısız çalışma bulunmaktadır. Benzer şekilde, örgüt bilimlerinde kişisel itibarın doğası ve süreç dinamikleri ile ilgili uluslararası literatürde kapsamlı çalışmalar bulunmaktayken, yerel/ulusal literatürde kişisel itibar kavramına ilişkin çalışmaların oldukça kısıtlı olduğu görülmektedir (bkz. Cömert ve Uzun, 2014; Demirbağ vd., 2020; Gök ve Çiftçioğlu, 2021; Küçük ve Demirbağ, 2021). Yerel literatüre katkı sağlama amacı taşıyan bu araştırmayla, Türkiye'de kişisel itibarın kavramsallaştırılması, örgütlerde itibarın nasıl oluştuğunun sistematik olarak ifade edilmesi ve karşılıklı olarak birbirini destekleyen bir dizi davranış bilimi teorisiyle bütünleştirilmesi çabasına girilmiştir. Ayrıca, bu çalışmada kişisel itibar kavramının yönetim açısından önemi teorik olarak ortaya konarak, çalışmanın kişisel itibara ilişkin gelecekteki araştırmalara ışık tutacağı düşünülmüştür.

Kişisel itibar, bireyin belirgin kişisel özelliklerini, başarılarını, sergilenen davranışlarını ve belirli bir süre boyunca doğrudan gözlemlenen veya ikincil kaynaklardan bildirildiği izlenimleri yansıtan ve başkalarının kolektif algılarında oluşan algısal bir kimliktir (Zinko vd., 2007: 165). Bu bağlamda kişisel itibar, diğer bireylerin bir bireyin özelliklerine ve/veya davranışlarına yönelik toplam algılamalarının bütününü yansıtmaktadır. Bireyler, günlük yaşamda pek çok şey için itibar geliştirmektedirler, ancak iş yaşamında itibarlar büyük olasılıkla bireylerin işlerini etkili bir şekilde yerine getirmelerine ve başkalarına karşı işbirlikçi olmalarına odaklanmaktadır. Bireyler, ödüllendirici veya faydalı buldukları belirli bir kimliği yaratma ve sürdürme hedeflerine sahip oldukları için izlenimlerini yönetmeye motive olmaktadırlar. Diğer bir deyişle bireyler, kendi itibarlarını oluşturmak için giriştikleri aktif, kasıtlı çabaların başkalarının kendileri hakkında oluşturduğu belirli izlenimler ve aktardıkları imajlar üzerinde kontrol etme arzusuyla motive olmaktadırlar. Bunu yapmak için, bireyler arzu ettikleri itibarla tutarlı davranışlar sergilemektedirler ve daha sonra gelecekte geliştirdikleri itibarı pekiştiren davranışları tutarlı bir şekilde sergilemek zorunda kalmaktadırlar. Yani, itibar zamanla oluşturulmakta, kalıcı bir etkiye sahip olabilmekte, genellikle proaktif olarak manipüle edilebilmekte ve yönetilmektedir. Olumlu itibara sahip bireyler, daha yetkin, daha yüksek statüye sahip ve daha güvenilir olarak algılanmaktadır ve bunların tümü, itibarlı bireye olumlu sonuçlar sunmaktadır. Bu olumlu sonuçlar; itibarlı bireye özerklik, güç ve kariyer başarısı gibi ödüller kazanma fırsatı vermektedir. İtibar ve güven arasındaki ilişki önemli bir bağlantı sunmaktadır. Bir bireyin sahip olduğu mevcut itibar, bu bireyin gelecekte sürekli olarak böyle davranacağına güvenme eğilimi yaratmakta ve bunun öngörülebilirlik duygusuna neden olabileceğini göstermektedir. Bu sayede, güven unsuru aracılığıyla tutarlı performans veya sorumlu davranış sergileyen birey, iyi bir itibar algısı oluşturabilmektedir.

Ulusal literatürde kişisel itibarı konu edinen çalışmaların yetersiz olması nedeniyle bu çalışma, konuyla ilgili daha fazla çalışma yapılmasını teşvik etmek amacıyla ele alınmıştır. Kişisel itibarın teorik yapısını daha iyi anlamak için konuyla ilgili daha fazla çalışma yapılması gereklidir. Çünkü, kişisel itibar kavramına ilişkin teorik ve ampirik olarak daha fazla çalışma yapılmasının araştırmacılara ve uygulayıcılara rehber olacağı düşünülmektedir. Gelecekteki araştırmalarda, kişisel itibarın bireylerin kariyerleri ve performansları üzerindeki etkileri ya da kurumsal itibar veya firma değeri üzerindeki etkileri incelenebilir. Özellikle, bireylerin uzun bir süre boyunca tasarlanan veya ortaya çıkan bilinçli ve hesaplanmış etki stratejileri aracılığıyla, itibarlarını nasıl geliştirdikleri ve sürdürdükleri, itibar artırma taktiklerinin/stratejilerinin seçimini nasıl yaptıkları araştırılabilir. İnsan kaynakları açısından, kişisel itibar hakkındaki bilgilerin potansiyel etkileri önemlidir ve yöneticiler için bu konu oldukça ilgi çekici olabilir. Çünkü, örgütlerde bireyleri işe alma, elde tutma veya terfi ettirme kararları alınırken itibar önemli bir husus olacaktır. Bu nedenle, farklı etki taktikleri ve stratejilerin bireylerin iş sonuçlarını etkilemesinde itibarın nasıl etkileşime girdiğinin belirlenebilmesi için daha fazla araştırmanın yapılmasına ihtiyaç vardır. 


\section{Beyan ve Açıklamalar (Declarations and Disclosures)}

Yazarların Etik Sorumlulukları (Ethical Responsibilities of Authors): Bu çalışmanın yazarı, araştırma ve yayın etiği ilkelerine uyduğunu kabul etmektedir.

Çıkar Çatışması (Conflicts of Interest): Yazar tarafından herhangi bir çıkar çatışması beyan edilmemiştir.

Finansal Destek (Funding): Yazar, çalışmanın hazırlanması ve/veya yayınlanması sürecinde herhangi bir finansal destek almamıştır.

Yazar Katkı Oranı (Author Contributions): Yazar; kavramlaştırma ve çalışma dizaynı, verilerin toplanması, verilerin analizi ve sonuçların yorumlanması, çalışmanın ilk/taslak halinin yazılması, çalışmanın gözden geçirilmesi ve düzenlenmesi/düzeltilmesi aşamalarından tek başına sorumlu olduğunu beyan etmektedir.

Intihal Denetimi (Plagiarism Checking): Bu çalışma, intihal tarama programı kullanılarak intihal taramasından geçirilmiştir.

\section{Kaynaklar}

Amaral, A., Powell, D. M., \& Ho, J. L. (2019). Why does impression management positively influence interview ratings? The mediating role of competence and warmth. International Journal of Selection and Assessment, 27(6), 315327.

Anglin, A. H., McKenny, A. F., \& Short, J. C. (2018). The impact of collective optimism on new venture creation and growth: A social contagion perspective. Entrepreneurship Theory and Practice, 42(3), 390-425.

Ashforth, B. E., \& Mael, F. A. (1989). Social identity theory and organization. The Academy of Management Review, 14(1), 20-39.

Baiman, S. (1991). Agency research in managerial accounting: A second look. Accounting, Organizations and Society, 15(4), 341-371.

Balmer, J. M. T. (1998). Corporate identity and the advent of corporate marketing. Journal of Marketing Management, 14(8), 963-996.

Bartels, J., Pruyn, A., Jong, de M., \& Joustra, I. (2007). Multiple organizational identification levels and the impact of perceived external prestige and communication climate. Journal of Organizational Behavior, 28(2), 173-190.

Baumeister, R. F., Zhang, L., \& Vohs, K. D. (2004). Gossip as cultural learning. Review of General Psychology, 8(2), 111121.

Becker, T. S. (1998). Integrity in organizations: Beyond honesty and conscientiousness. Academy of Management Review, 23, 154-161.

Boekaerts, M. (2010). Motivation and self-regulation: Two close friends. Motivation and Achievement Advances in Motivation and Achievement, 16B, 69-108.

Boekhorst, J. A. (2015). The role of authentic leadership in fostering workplace inclusion: A social information processing perspective. Human Resource Management, 54(2), 241-264.

Bromley, D. B. (1993). Reputation, image and impression management. New York: John Wiley \& Sons.

Certo, T. (2003). Influencing initial public offering investors with prestige: Signaling with board structures. The Academy of Management Review, 28(3), 432-446.

Cömert, N., \& Uzun, A.K. (2014). Bağımsız denetçiler için itibar yönetimi. İtibar Yönetimi (ss. 343-359). Beta Yayıncılık.

Chai, J. C. Y., \& Dibb, S. (2013). How consumer acculturation influences interpersonal trust. Journal of Marketing Management, 30(1-2), 60-89.

Chen, Z., Takeuchi, R., \& Shum, C. (2013). A social information processing perspective of coworker influence on a focal employee. Organization Science, 24(6), 1618-1639.

Choi, A. (2020). Social comparison in fashion blogging: "Creative self" as the new genre in fashion communication. Journal of Fashion Marketing and Management, 24, 651-665.

Davies, G., \& Rosa, C. (2009). The leader's role in managing reputation building and maintaining trust in the 21st century. (Ed.) J. Klewes, R. Wreschniok, Reputation capital (pp. 311-323). Springer.

Demirbağ, O., Demir, H., \& Yozgat, U. (2020). Political will, political skill, network resources and personal reputation: A serial two-mediator model. Central European Management Journal, 28(3), 26-56.

Dowling, G. (2001). Creating corporate reputations. Oxford: Oxford University Press. 
Dunn, J. R. (2008). A multidimensional view of personal reputations. Academy of Management Proceedings, 2008(1), 16.

Eddleston, K. A. (2009). The effects of social comparisons on managerial career satisfaction and turnover intentions. The Career Development International, 14(1), 87-110.

Farley, S. D. (2011). Is gossip power? The inverse relationships between gossip, power, and likability. European Journal of Social Psychology, 41, 574-579.

Ferris, G. R., Hochwarter, W. A., Buckley, M. R., Harrell-Cook, G., \& Frink, D. D. (1999). Human resources management: Some new directions. Journal of Management, 25(3), 385-415.

Ferris, G. R., Blass, F. R., Douglas, C., Kolodinsky, R. W., \& Treadway, D. C. (2003). Personal reputation in organizations. (Ed.) J. Greenberg, Organizational behavior: The state of the science (pp. 211-246). Mahwah, NJ: Erlbaum.

Ferris, G. R., Treadway, D. C., Kolodinsky, R. W., Hochwarter, W. A., Kacmar, C. J., Douglas, C., \& Frink, D. D. (2005). Development and validation of the political skill inventory. Journal of Management, 31(1), 126-152.

Ferris, G. R., Harris, J. N., Russell, Z. A., Blass, F. R., Ellen, B. P., \& Martinez, A. D. (2014). The role of reputation in the organizational sciences: A multilevel review, construct assessment, and research directions. (Eds.) M. Buckley, R. Halbesleben \& A. R. Wheeler, Personnel and human resources management (pp. 241-303). UK: Emerald Group Publishing.

Festinger, L. (1954). A theory of social comparison processes. Human Relations, 7, 117-140.

Foley, S., Ngo, H. Y., \& Loi, R. (2016). Antecedents and consequences of upward and downward social comparisons: An investigation of Chinese employees. International Journal of Organizational Analysis, 24(1), 145-161.

Fombrun, C. J., \& Shanley, M. (1990). What's in a name? Reputation building and corporate strategy. The Academy of Management Journal, 33(2), 233-258.

Fombrun, C. J. (1996). Reputation: Realizing value from the corporate image. Boston, Massachusetts: Harvard Business School Press.

Foste, E. A., \& Botero, I. C. (2012). Personal reputation: Effects of upward communication on impressions about new employees. Management Communication Quarterly, 26(1), 48-73.

Frazier, M. L., \& Bowler, W. M. (2012). Voice climate, supervisor undermining, and work outcomes: A group-level examination. Journal of Management, 41(3), 841-863.

Gaines-Ross, L. (2000). CEO reputation: A key factor in shareholder value. Corporate Reputation Review, 3(4), 366-370.

Gerber, J. P., Wheeler, L., \& Suls, J. (2018). A social comparison theory meta-analysis 60+ years on. Psychological Bulletin, 144(2), 1-69.

Goldin, C. (2016). Human capital. (Ed.) C. Diebolt \& M. Haupert, Handbook of cliometrics (pp. 1-40). Heidelberg, Germany: Springer Verlag.

Gowler, D., \& Legge, K. (1989). Rhetoric in bureaucratic careers: Managing the meaning of management success. (Ed.) M. B. Arthur, D. T. Hall \& B. S. Lawrence, Handbook of career theory (pp. 437-453). NY: Cambridge University Press.

Gök, B., \& Çiftçioğlu, A. (2021). Prestij, yönetim kurulu ve özdeşleşme ilişkisini anlamaya yönelik bir çalışma. International Journal of Social Inquiry, 14(1), 199-230.

Graen, G. B., \& Uhl-Bien, M. (1995). Relationship-based approach to leadership: Development of leader-member exchange (LMX) theory of leadership over 25 years: Applying a multi-level multi-domain perspective. Leadership Quarterly, 6, 219-247.

Graffin, S. D., Pfarrer, M. D., \& Hill, M. W. (2012). Untangling executive reputation and corporate reputation: Who made who. (Ed.) T. G. Pollock \& M. L. Barnett, The Oxford handbook of corporate reputation (pp. 221-239). Oxford UK: Oxford University Press.

Greenberg, J. (1990). Looking fair vs. being fair: Managing impressions of organizational justice. (Ed.) B.M. Staw \& L.L. Cummings, Organizational behavior (pp. 111-157). Greenwich, CT: JAI Press.

Hall, R. (1992). The strategic anaysis of intangible resources. Strategic Management Journal, 3(2), 135-144.

Hall, A. T., Blass, F. R., Ferris, G. R., \& Massengale, R. (2004). Leader reputation and accountability in organizations: Implications for dysfunctional leader behavior. The Leadership Quarterly, 15, 515-536.

Heo, M., Toomey, N., \& Song, J. S. (2020). Self-evaluation of knowledge sharing through the lens of social comparison theory. VINE Journal of Information and Knowledge Management Systems, 50(2), 291-304. 
Hochwarter, W., Ferris, G. R., Zinko, R. A., Arnell, B., \& James, M. S. (2007). Reputation as a moderator of political behavior-work outcomes relationships: A two-study investigation with convergent results. The Journal of Applied Psychology, 92(2), 567-576.

Hoekstra, H. A. (2011). A career roles model of career development. Journal of Vocational Behavior, 78(2), $159-173$.

Hogan, J., \& Holland, B. (2003). Using theory to evaluate personality and job-performance relations: A socioanalytic perspective. Journal of Applied Psychology, 88(1), 100-112.

Howe, M., Chang, C. H. (D.), \& Johnson, R. E. (2013). Understanding affect, stress, and well-being within a self-regulation framework. (Ed.) P. L. Perrewé, C. C. Rosen \& J. R. B. Halbesleben, The role of emotion and emotion regulation in job stress and well being (pp. 1-34). Emerald Group Publishing.

Jazaieri, H., Allison, M. L., Campos, B., Young, R. C., \& Keltner, D. (2019). Content, structure, and dynamics of personal reputation: The role of trust and status potential within social networks. Group Processes \& Intergroup Relations, 22(7), 964-983.

Jian, M., \& Lee, K. W. (2011). Does CEO reputation matter for capital investments? Journal of Corporate Finance, 17(4), 929-946.

Johnson, D. E., Erez, A., Kiker, D. S., \& Motowidlo, S. J. (2002). Liking and attribution of motives as mediators of the relationships between individuals' reputations, helpful behaviors, and raters' reward decisions. Journal of Applied Psychology, 87, 808-815.

Karoly, P. (1993). Mechanisms of self-regulation: A systems view. Annual Review of Psychology, 44, 23-52.

Kilduff, M., \& Krackhardt, D. (1994). Bringing the individual back in: A structural analysis of the internal market for reputation in organizations. Academy of Management Journal, 37, 87-108.

Küçük, M., \& Demirbağ, O. (2021). Performans yönetim sisteminin doğruluğunun itibar ile ilişkisinde iş performansının aracı, lider-üye etkileşimin düzenleyici rolü. İstanbul Ticaret Üniversitesi Sosyal Bilimler Dergisi, 20(40), 44-69.

Knoke, D. (1983). Organization sponsorship and influence reputation of social influence associations. Social Forces, 61, 1065-1087.

Laird, D. M., Zboja, J. J., \& Ferris, G. R. (2012). Partial mediation of the political skill-reputation relationship. Career Development International, 17(6), 557-582.

Laird, D. M., Zboja, J. J., Martinez, A. D., \& Ferris, G. R. (2013). Performance and political skill in personal reputation assessments. Journal of Managerial Psychology, 28(6), 661-676.

Levy, D. A., \& Nail, P. R. (1993). Contagion: A theoretical and empirical review and reconceptualization. Genetic, Social \& General Psychology Monographs, 119(2), 235-285.

Limerick, D., \& Cunnington, B. (1993). Managing the new organisation: A blueprint for networks and strategic alliances. San Francisco, CA: Jossey-Bass.

Liu, Y., Ferris, G. R., Zinko, R., Perrewé, P. L., Weitz, B., \& Xu, J. (2007). Dispositional antecedents and outcomes of political skill in organizations: A four-study investigation with convergence. Journal of Vocational Behavior, 71, 146-165.

Locke, E. A., \& Latham, G. P. (2002). Building a practically useful theory of goal setting and task motivation - A 35-year odyssey. American Psychologist, 57, 705-717.

McAllister, D. J. (1995). Affect-and cognition-based trust as foundations for interpersonal cooperation in organizations. Academy of Management Journal, 38(1), 24-59.

McCrory, P., Cobley, S., \& Marchant, P. (2013) The effect of psychological skills training (pst) on self-regulation behavior, self-efficacy, and psychological skill use in military pilot-trainees. Military Psychology, 25(2), 136-147.

Milewicz, J., \& Herbig, P. (1994). Evaluating the brand extension decision using a model of reputation building. Journal of Product and Brand Management, 3, 39-47.

Mintzberg, H. (1983). Power in and around organizations. Englewood Cliffs, NJ: Prentice-Hall.

Moye, M. J., \& Henkin, A. B. (2006). Exploring associations between employee empowerment and interpersonal trust in managers. Journal of Management Development, 25(2), 101-117.

Pharoah, A. (2003). Corporate reputation: The boardroom challenge. Corporate Governance: The International Journal of Business in Society, 3(4), 46-51.

Ranft, A., Zinko, R., Ferris, G. R., \& Buckley, M. R. (2006). Marketing the image of management: The costs and benefits of CEO reputation. Organizational Dynamics, 35(3), 279-290. 
Rego, A., Owens, B., Yam, K. C., Bluhm, D., Cunha, M. P., Silard, A., Gonçalves, L., Martins, M., Simpson, A. V., \& Liu, W. (2017). Leader humility and team performance. Journal of Management, 1-25. doi:10.1177/0149206316688941

Rotter, J. (1971). Generalized expectancies for interpersonal trust. Amencan Psychologist, 26, 443-452.

Salancik, G. R., \& Pfeffer, J. (1978). A social information processing approach to job attitudes and task design. Administrative Science Quarterly, 23(2), 224-253.

Sanchez-Marin, G., \& Baixauli-Soler, S. (2014). CEO reputation and top management team compensation: The moderating role of corporate governance. Management Decision, 52(3), 540-558.

Schlenker, B. R., Weigold, M. F., \& Schlenker, K. A. (2008). What makes a hero? The impact of integrity on admiration and interpersonal judgment. Journal of Personality, 76, 323-355.

Schwaiger, M. (2004). Component and parameters of corporate reputation an emprirical study. Schmalenbach Business Review, 56(1), 46-71.

Spence, M. (2002). Signaling in retrospect and the informational structure of markets. American Economic Review, 92 , 434-459.

Tajfel, H., \& Turner, J. C. (1979). An integrative theory of inter-group conflict. (Ed.) W. G. Austin, S. Worchel, The social psychology of intergroup relations. CA: Brooks/Cole.

Tedeschi, J. T., \& Melburg, V. (1984). Impression management and influence in the organization. (Ed.) S. B. Bacharach \& E. J. Lawler, The sociology of organizations (pp. 31-58). Greenwich, CT: JAI Press.

Thomas, G. F., Zolin, R., \& Hartman, J. L. (2009). The central role of communication in developing trust and its effect on employee involvement. Journal of Business Communication, 46(3), 287-310.

Tinsley, C. H., O'Connor, K. M., \& Sullivan, B. A. (2002). Tough guys finish last: The perils of a distributive reputation. Organizational Behavior and Human Decision Processes, 88, 621-642.

Totterdell, P., Kellett, S., Teuchmann, K., Briner, R. B. (1998). Evidence of mood linkage in work groups. Journal of Personality and Social Psychology, 74(6), 1504-1515.

Türk Dil Kurumu. https://www.tdk.gov.tr/ (Erişim Tarihi, 20 Kasım 2021).

Treadway, D. C., Adams, G. L., Ranft, A. L., \& Ferris, G. R. (2009). A meso-level conceptualization of CEO celebrity effectiveness. The Leadership Quarterly, 20(4), 554-570.

Ullrich, J., Christ, O., \& Rick R. V. (2009). Substitutes for procedural fairness: Prototypical leaders are endorsed whether they are fair or not. Journal of Applied Psychology, 94(1), 235-244.

Van Hooft, E. A. J., Wanberg, C. R., \& Van Hoye, G. (2013). Moving beyond job search quantity: Towards a conceptualization and self-regulatory framework of job search quality. Organizational Psychology Review, 3(1), 3-40.

Van Knippenberg, D., \& Hogg, M. A. (2003). A social identity model of leadership effectiveness in organizations. Research in Organizational Behavior, 25, 243-295.

Walker, K. (2010). A systematic review of the corporate reputation literature: Definition, measurement, and theory. Corporate Reputation Review, 12(4), 357-387.

Wanberg, C. R., Kanfer, R., \& Banas, J. T. (2000). Predictors and outcomes of networking intensity among unemployed job seekers. Journal of Applied Psychology, 85, 491-503.

Whitmeyer, J. M. (2000). Effects of positive reputation systems. Social Science Research, 29, 188-207.

Yang, F., Huang, X., \& Wu, L. (2019). Experiencing meaningfulness climate in teams: How spiritual leadership enhances team effectiveness when facing uncertain tasks. Human Resource Management, 58(2), 155-168.

Yukl, G. (1998). Leadership in organizations. Upper Saddle River, NJ: Prentice Hall.

Zimmerman, B. J. (2000). Attaining self-regulation: A social cognitive perspective. (Ed.) M. Boekaerts, P. R. Pintrich, \& M. Zeidner, Handbook of self-regulation (pp. 13-39). San Diego, CA: Academic Press.

Zinko, R., Ferris, G. R., Blass, F. R., \& Laird, M. D. (2007). Toward a theory of reputation in organizations. Research in Personnel and Human Resources Management, 26, 163-204.

Zinko, R., Furner, C. P., Royle, T., \& Hall, A. (2010). Self-perceptions of our personal reputations: The mediating role of image in the development of organizational citizenship behaviors. Journal of International Management Studies, 5(1), 1-9.

Zinko, R., Ferris, G. R., Humphrey, S. E., Meyer, C. J., \& Aime, F. (2012). Personal reputation in organizations: Two-study constructive replication and extension of antecedents and consequences. Journal of Occupational and Organizational Psychology, 85(1), 156-180. 
Zinko, R. (2013). A continued examination of the inverse relationship between political skill and strain reactions: Exploring reputation as a mediating factor. Journal of Applied Social Psychology, 43, 1750-1759.

Zinko, R., \& Rubin, M. (2015). Personal reputation and the organization. Journal of Management \& Organization, 21(2), 217-236.

Zinko, R., Furner, C. P., Prati, L. M., Heyden, M. L. M., \& Tuchtan C. (2017a). A study of negative reputation in the workplace. Journal of Career Assessment, 25(4), 632-649.

Zinko, R., Tuchtan, C., Hunt, J. B., Meurs, J. A., Furner, C. P., \& Prati, L. (2017b). Gossip: A channel for the development of personal reputation. International Journal of Organizational Analysis, 25, 516-535.

Zinko, R., Furner, Z. Z., Hunt, J., \& Dalton, A. (2017c). Establishing a reputation. Journal of Employment Counseling, 54(2), 87-96. 